\title{
Class and everyday media use
}

\author{
A case study from Norway
}

\author{
Jan Fredrik Hovden ${ }^{I} \&$ Lennart Rosenlund ${ }^{\text {II }}$ \\ 'Department of Information Science and Media Studies, University of Bergen, Norway \\ IIDepartment of Media and Social Sciences, University of Stavanger, Norway
}

\begin{abstract}
In this article, we consider how contemporary media use is structured by social class, following the theoretical and methodical framework derived from Bourdieu's book Distinction, published in 1984, with a detailed study of everyday use of media platforms, brands, and content among Norwegian citizens $(N=2,064)$. First, we analyse how such media use varies in the overall social space using multiple correspondence analysis. Second, we independently explore the main differences and groupings of media practices, combining multifactor analysis and cluster analysis. While identifying important gender and generational differences, this study clearly shows how media use inside both younger and older generations are marked by class differences, which we argue demonstrates the fundamental and continuing importance of class for understanding mediated lifestyles.
\end{abstract}

Keywords: social class, media use, Scandinavia, Bourdieu, homology thesis

\section{Introduction}

In an age of an unprecedented abundance of media content for our enjoyment, to consume wherever and whenever we want, much of it for free or within financial reach to most people, are social classes still relevant for understanding our daily media use? While class was a central analytical category in several now-classic works on audiences - not least in the tradition of British cultural studies (e.g., Morley, 1980), the later developments of theories, methodology, and debates in class sociology following the "cultural turn" arguably appears to have had little impact on the field of audience studies' research on shifting audience practices following digitalisation - for example, the uses and affordances of new social media (Baym, 2015), the "participatory turn" (Livingstone, 1999), the "digital divide" (Tsatsou, 2011), decline of the use of traditional media and formats, not least news (Blekesaune et al., 2010), and cross-media use (Hasebrink \& Domeyer, 2012). That is not to say that audience studies do not regularly analyse patterns of social differences in media practices and discuss their consequences, but rather that it typically happens without resorting to the theory or language of class - probably related to the strong discourse of the "death of class" as a relevant concept

Hovden, J. F., \& Rosenlund, L. (2021). Class and everyday media use: A case study from Norway. Nordicom Review, 42(S3), 129-149. https://doi.org/10.2478/nor-2021-0030 
for the social sciences in the 1980s and 1990s (Atkinson, 2015). Whatever the reason, the two traditions appear, unfortunately, to converse little about these issues, indicated by the typical lack of references to seminal works from each other's field.

In later class sociology, dedicated studies of media use are also relatively rare. It has, however, has often been an element in more general studies arguing for the role of social class for structuring cultural lifestyles following the empirical tradition from Pierre Bourdieu (1984). Some international examples can be found in Coulangeon and Duval (2014) and Bennet and colleagues (2009). In Norway, there are several examples of analyses in this tradition (Danielsen, 2006; Flemmen et al., 2018; Gripsrud \& Hovden, 2000; Gripsrud et al., 2011; Hjellbrekke et al., 2015; Mangset, 2012; Rosenlund, $2000,2009,2019)$. For examples from other Nordic countries, see the other articles in this special issue.

In this article, we apply the tools of class analysis to a study of everyday media use patterns in Norway. Following the tradition of Pierre Bourdieu (1984), we analyse structural similarities (homologies) between social class differences and differences in people's media use, using factorial analysis (multiple correspondence analysis and multiple factor analysis) on a representative sample of Norwegian citizens. Following a short recapitulation of Pierre Bourdieu's central ideas on (and later critique of) the relationship between class and lifestyles - which we consider media use to be a part of - and description of the data and methodological approach, the analysis is divided into two parts. In the first, we sketch the social space (based on indicators of people's resources, their capital) and look at how media practices are distributed between different social classes. In the second, complementary part, we reverse the analysis and sketch a space of everyday media use (use of platforms and specific services, and interest in television and news genres), and look at how class fractions are distributed along the major differences found (a precursor to this analysis is presented in Moe et al., 2019). Our core argument is not simply that many elements of our everyday media use are distributed quite differently between social classes, but that social class is a fundamental explanatory category for understanding differences in media use.

\section{Class, culture, homologies}

For the discussion of the relevance of class for understanding lifestyles in modern societies, Pierre Bourdieu's Distinction (1984) is still a seminal work. He argued for a new, relational model of social class grounded in our relative fundamental resources (various forms of capital - economic, cultural, educational, etc.), our deep-seated social dispositions (as part of our habitus), and our life course (social trajectory). A central idea was what has later been called the "homology thesis". Society has a double existence (Bourdieu \& Wacquant, 1992): first, in social positions - the objectivity of the first order; and second, in our social and symbolic practices (which include the use and appreciation of media and culture) - the objectivity of the second order. This is made possible by the mediating structure of habitus, our system of dispositions for acting, thinking, and orientation in the social world - a structured yet structuring structure. Being a systematic product of the first order (our place in the structures of inequality), Bourdieu hypothesised that social classes and lifestyles would often differ along parallel lines (if never perfectly so) and bear a similar mark across cultural fields and 
practices, for example, as a preference for symbolically complex works in both music and literature.

While Bourdieu's model integrated central aspects of earlier class models (not least Max Weber's ideas of the multidimensional nature of social inequality, the central role of status differences, and his concept of lifestyles), it also broke with many of these. He discarded the preoccupation, following Marx, with work relations and conditions as the basis for classes (e.g., Goldthorpe, 1980; Wright, 1985), instead suggesting that class positions are based in our relative position in the distribution of societies' fundamental resources (forms of capital). Most noted, perhaps, was his emphasis on cultural capital as a vital resource for domination and reproduction in modern societies (generalising the argument for its role in educational reproduction made in Bourdieu \& Passeron, 1990). Crucial also was his view on the fundamental inseparableness of class from other social categories (e.g., age, gender, ethnicity), using the analogy of the impossibility of separating the colour of a lemon and its sour taste (Bourdieu, 1984), a phenomenon which in later literature is referred to as intersectionality (Adkins \& Skeggs, 2005). In this way - greatly aided by the help of the relational methodology of correspondence analysis (Le Roux et al., 2000) - Bourdieu broke with the (still) dominant tradition in Anglo-American social science which Blumer (1956) named "variable sociology", the idea that the effect of a single variable can be isolated from others (a fundamental tenet of regression analysis), which for him was a misrecognition of the multivariate reality of the social world.

Bourdieu's book has been criticised on many accounts. It has, naturally, been condemned along with the rest of class sociology by those arguing that class is dead, or at least has become much less central through processes of increasing individualisation, linked to processes of social mobility, erosion of traditional occupational structures, the expansion of the educational system, and so forth (e.g., Beck, 1992; Giddens, 1991; Inglehart, 1990). Regarding the more specific critique of Bourdieu's book, a central objection has been that it is too bound up with a particular French historical situation to be relevant for studies of other societies. This concerns, in particular, the importance of cultural capital for stratification and status (Chan \& Goldthorpe, 2004; Lamont \& Lareau, 1988). Following this, others have criticised Bourdieu for disregarding the eclecticism of tastes (Peterson, 1992), failing to see the relatively autonomous role of popular culture in favour of an exclusive focus on legitimate culture (Grignon \& Passeron, 2019), not allowing enough room for individual variety and plasticity (Lahire, 2004), and otherwise overemphasising the rigidness and unified nature of the habitus, arguing for the need for negotiating Bourdieu's central concepts into a looser, more pliable and contingent set of relations than they occupy in Distinction (Bennett et al., 2009). While we think that some of these reservations about Bourdieu's work have been productive in suggesting new directions for research, we also like to stress that some of these critiques appear to disregard important parts of his work. His book with Passeron on the cultural orientation of university students (Bourdieu \& Passeron, 1979), for example, emphasises not just the importance of popular culture (e.g., knowledge of film) as cultural capital, but also, preceding the debate following Peterson (1992), the distinctive value and class-specific nature of cultural eclecticism.

While not writing very much about class differences in media use, such use is an important part of Distinction's mapping of cultural lifestyles, and thus, the overarching 
argument about a systematic homology between class and cultural lifestyles. With the proliferation of new forms of media use and their increasing importance in our personal and public lives, we think this question is still an under-explored issue, with relevance for both audience studies and class sociology.

\section{Data and methodology}

The data for this analysis comes from the Public connection survey (Moe et al., 2019), distributed in late 2017 and using a nationally representative web panel of Norwegian citizens over 15 years of age $(N=2,064)$. An invitation to the survey was sent via email to 6,502 respondents; 39 per cent opened it, and of these, 85 per cent responded. The resulting sample appears to be similarly representative of the population as most large-scale general national surveys, with an overrepresentation of citizens with higher education and over 60 years of age, but no apparent bias in terms of geography or gender (Gallup, 2017).

Within the framework of geometric data analysis methods (which includes correspondence analysis and principal component analysis), there are two main methodological strategies available to the study of how parts of lifestyles - in our case, everyday media use - is related to social class (Lebart et al., 1984). One is to construct a model of the social space (i.e., the space of classes) using indicators of capital, and then project the lifestyle variables onto this space. Here, the prime goal of the analysis is to understand the formation of and differences between social classes, where lifestyles act as characterising elements. A reverse strategy is to construct a space of lifestyles and project indicators related to social class (occupation, education, etc.) onto this. In the latter case, the priority is to understand the main differences in lifestyles, with class as a characterising variable. In this article, we combine these two strategies to explore the homologies (structural similarities) between the two spaces.

The social space of Norway is first reconstructed using specific multiple correspondence analysis (MCA) (Le Roux \& Rouanet, 2010) and nine indicators of capital. We look at how some media practices are distributed between the classes and retain the main class fractions for later analysis. Following this, we construct the space of everyday media use using four groups of variables (138 in total): daily use of various types of media platforms (e.g., net newspapers, social media); regular use of specific brands and services (channels, publications, net sites, etc.); genres of news one likes to read in the newspapers (e.g., international politics or sport); and specific television programmes one likes, chosen from a list of current programmes.

In our case, the media variables are quite heterogeneous and grouped in four distinct subspaces - a situation which is challenging for traditional MCA (Le Roux \& Rouanet, 2010). ${ }^{1}$ For this reason, we construct the space of everyday media use using an alternative, relatively recent and still little-used approach in the social sciences: multiple factor analysis (MFA). MFA combines aspects of well-established geometrical methods like MCA - including the extraction of principal axes, canonical correlation techniques and Procrustes analysis- to extend the logic of such methods to multiple contingency tables (Pagès \& Bécue-Bertaut, 2006). MFA is an extension of the philosophy of MCA to a situation where the variables have a clear group structure, as is our case. MFA also offers useful metrics for studying the relationship between the variable groups, including 
correlations between the principal axes from different subspaces, and between such axes and axes in the global space. In this way, MFA offers a promising tool for investigating structural homologies not just between social class and lifestyles, but also between different dimensions of lifestyles (here, various forms of media use).

The first analysis briefly sketches the Norwegian social space and how everyday media practices are placed in this, while the second sketches the space of everyday media use - that is, the media use patterns independent of class or any other social differences.

\section{The Norwegian social space}

The social space is the space of relations between individuals and social classes as given by one's capital - unequal, fundamental societal resources which constitute our possibilities in the social world - and is inexorably bound up with how we relate to and act in this world (Bourdieu, 1984). Our lifestyles, of which our everyday media use is a central part, is for Bourdieu, as for Weber (who called them Lebensstile), not merely a matter of conscious selection of what is available (Lebenführung), but also dependent on our objective chances for realising them (Lebenschancen).

Nine indicators of capital and social position are used to sketch the Norwegian social space (see Table 1):

Cultural capital

- Cultural resources in the parental home (agreement or disagreement with the statement, "I was raised in a home with many books, and interest in music, art, and culture")

- Education level

- Father's education level

- Field of education (vocational "soft" subjects - e.g., studies in humanities and teaching - or "hard" subjects - e.g., engineering, physics, business studies, etc.)

Economic capital

- Gross household income

- Bank savings

- Value of home

Occupation

- Type of occupation (unskilled and skilled worker, top leader, functionary or other leader, self-employed, or other)

- Sector of occupation (private, municipal, or county/state)

This gives a solution with two main axes: the first is related to capital volume, and the second pertains to capital composition (see Figure 1). The first (vertical) axis separates individuals with generally higher economic and symbolic resources - including cultural capital - from those with less (e.g., professional classes versus skilled and unskilled workers). The second (horizontal) axis separates individuals according to if one's resources are skewed more towards economic resources or symbolic cultural resources 
(e.g., separating business leaders from professors and finance workers from teachers). This basic model is very similar to analyses of the Norwegian social space using comparable data (e.g., Rosenlund, 2015). ${ }^{2}$

As a rough measure of class position, the individuals in the resulting plane were divided into a $3 \times 3$ grid, with roughly equal distances and numbers, dividing by class volume along axis 1 (high, medium, low) and by capital composition along axis 2 (emphasis on cultural capital, balanced capital, emphasis on economic capital), which combine in nine class fractions. Some general differences between higher and lower, and cultural and economic, class fractions for some forms of daily media use are shown in Tables A1-A6 (see Appendix 1).

Table 1 Indicators used to construct the Norwegian social space (categories and contributions)

\begin{tabular}{lccc}
\hline & $\begin{array}{c}\text { Number of } \\
\text { categories }\end{array}$ & $\begin{array}{c}\text { Contribution to } \\
\text { axis 1 }\end{array}$ & $\begin{array}{c}\text { Contribution to } \\
\text { axis 2 }\end{array}$ \\
\hline Cultural resources in the parental home & 4 & 10.9 & 10.0 \\
Education level & 5 & 10.9 & 23.8 \\
Father's education level & 5 & 10.1 & 13.0 \\
Field of education & 3 & 8.1 & 8.5 \\
Cultural capital (total) & $\mathbf{1 7}$ & $\mathbf{4 0 . 0}$ & $\mathbf{5 5 . 3}$ \\
\hline Gross household income & 7 & 8.7 & 14.3 \\
Bank savings & 7 & 9.0 & 4.7 \\
Value of home & 6 & 8.5 & 10.7 \\
Economic capital (total) & $\mathbf{2 0}$ & $\mathbf{2 6 . 2}$ & $\mathbf{2 9 . 7}$ \\
\hline Type of occupation & 7 & 6.3 & 10.9 \\
Sector of occupation & 3 & 6.3 & 4.1 \\
Occupation (total) & $\mathbf{1 0}$ & $\mathbf{1 2 . 6}$ & $\mathbf{1 5 . 0}$ \\
\hline
\end{tabular}

Not unexpectedly, the central aspects of Norwegians' media use diverge along familiar class lines. First, the media use of the upper classes (top of the map) tends to be oriented much more towards political and international news (not least when it comes to newspapers and news sites used) than the lower classes. The former are, for example, three times more likely than the latter to say they regularly read a foreign newspaper. The upper classes also express more interest in reading about national and international politics, but there are only small differences in interest and readership of local news and local politics. Second, the upper classes appear to have a generally higher interest in and consumption of national news and everything related to the national debate - not just with their greater interest in newspapers' opinion pieces and debate programmes (e.g., Dagsnytt 18), but also all kinds of political infotainment (e.g., Nytt på Nytt, a comedy show about current news). They also have higher use of so-called quality newspapers - the large national broadsheets (e.g., Aftenposten) and smaller, intellectual newspapers like Klassekampen and Morgenbladet. Also notable is their higher preference for public service channels (NRK) over commercial broadcast channels (e.g., TV2, P4). 
Figure 1 Everyday media use in the Norwegian social space (MCA, axis 1-2)

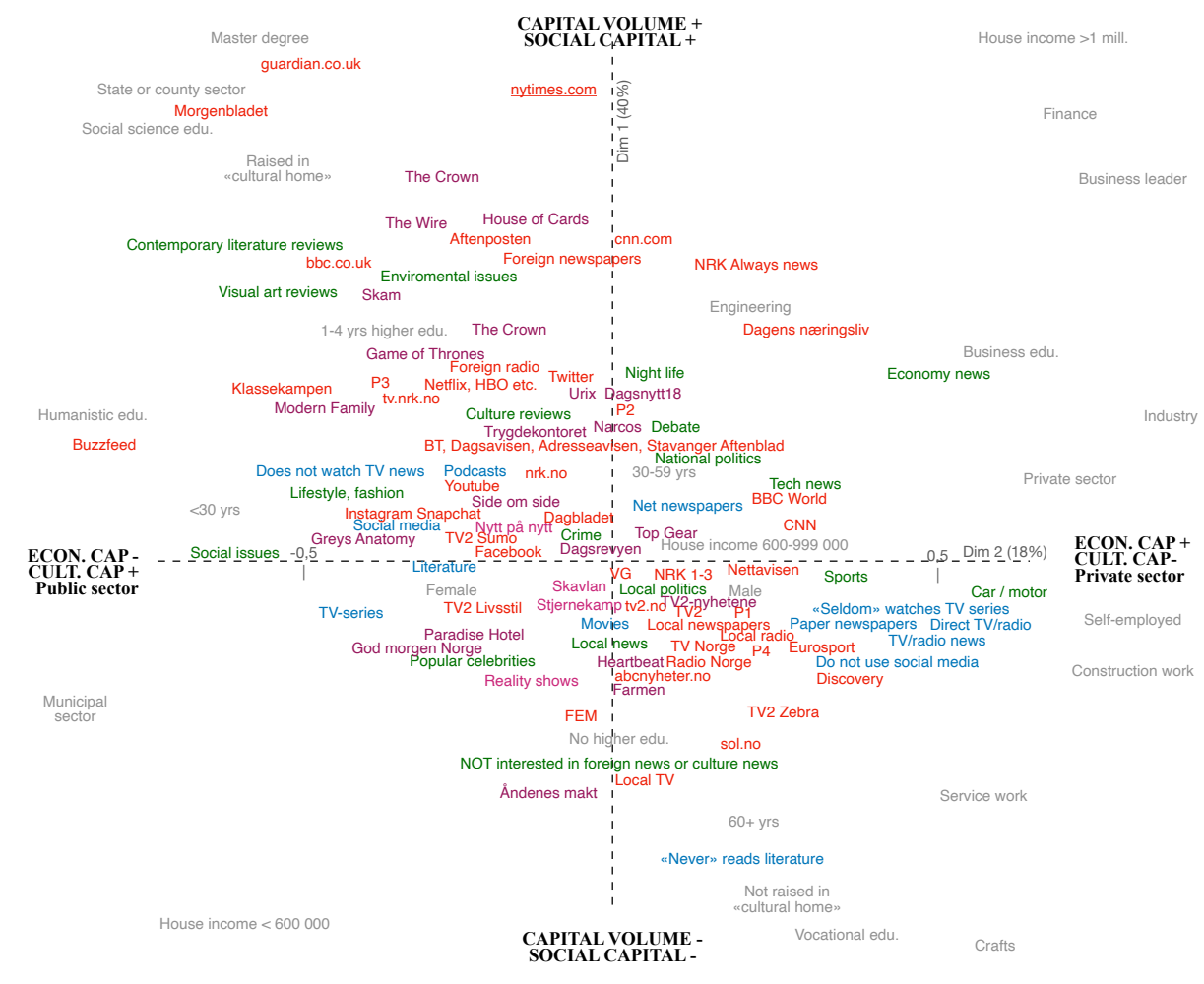

Source: Created by the authors

At the same time, there are marked differences in media use related to the kinds of resources people have. Not only reading "intellectual" newspapers, but also interest in culture reviews, television drama, and literature are more common among those with a leaning towards cultural capital, and this is also true for interest in celebrity culture, lifestyle, and fashion. The economic fraction, on the other hand-more often men, and older - are more often interested in business news, sports, and so forth.

While we could explore the differences in much more detail, we are for now satisfied with replicating the general findings in similar studies of systematic links between social class and everyday media use in Scandinavia, related to both capital volume and capital composition (Lindell \& Hovden, 2018; Prieur et al., 2008; Rosenlund, 2000). What our analysis - and similar analyses of the social space - does not demonstrate, however, is how differences in media use vary regardless of class. This is important for several reasons. First, there clearly exist forms of culture use - not least in popular culture - which are characterised by small differences between the classes (e.g., the popularity of the television series Seinfeld among Norwegian students in the late 1990s, or the propensity of regularly going to a pub in Britain; see Gripsrud \& Hovden, 2000; Benett et al., 2009). Second, studies have also found that cultural divides are often (more) strongly divided by other factors - for example, gender or age - and moreover, that this varies by cultural field (e.g., Bennett et al., 2009). While this does not necessarily constitute a problem for Bourdieu's basic argument, it emphasises the importance - as we do in the next section - of studying the internal divisions in media use regardless of people's place in the social space. 


\section{The space of everyday media use}

In this part, we focus on the complex interrelationships between daily media practices on an individual level, akin to what some media researchers call media repertoires (Hasebrink \& Popp, 2006). We identify the most significant differences between people (i.e., those that explain most of the variation in the statistical table) and look at how these principal differences in media use are related to social characteristics, including, but not limited to, social class. Where the former analysis ask how classes are characterised by different media use, we now reverse the analysis, a strategy which - as science should do - puts this idea at risk, as it provides a real possibility of finding that class relations are of little relevance to our use of the media.

The space of everyday media use is constructed by combining the analyses of four variable groups, partly nested, combining a total of 138 variables:

- Group A asks about use of general media platforms and technologies.

- Group B asks about use of specific brands on these platforms.

- Group C asks about interest in news categories in newspapers.

- Group D asks about interest in television programmes.

Our analysis proceeds in two steps. First, we investigate what in MFA is called the pseudoseparate analyses. This is analogous to doing four separate MCAs (one for each variable group), identifying the principal axes which explain most of the differences in each case, and interpreting the oppositions separately (e.g., asking what divides people most in their television preferences). Second, we look at how all these differences combine in a shared space - what MFA calls the global analysis. Methodologically, this last step is done by a logic analogous to that of a PCA using individuals' positions on the extracted principal axes of differences (for a more detailed discussion, see Pagès, 2014). The main differences for each variable group and some of their statistical properties (including their importance in the total analysis and their correlation with the global axes) are provided in Tables $2 \mathrm{a}-2 \mathrm{~d}$. These statistics show that the four groups of media practices are, overall, relatively homologous (that is, their internal divisions tend to correlate), but also that internal divisions in some aspects of media use (especially in regard to the most popular forms of culture, for example, daily use of televised drama) is less related to others (e.g., interest in different newspapers genres).

Table 2a The pseudoseparate analyses of the overall MFA: Characteristics and selected statistics for general media platforms and technologies

\begin{tabular}{|c|c|c|c|c|c|c|c|c|c|}
\hline \multirow[b]{2}{*}{ Variable } & \multirow[b]{2}{*}{ Pseudoseparate axes } & \multicolumn{4}{|c|}{$\begin{array}{c}\text { Absolute contribution to } \\
\text { global axes } \\
\text { (bold = above average) }\end{array}$} & \multicolumn{4}{|c|}{$\begin{array}{l}\text { Correlation with } \\
\text { global axes } \\
(\text { bold }=>.30)\end{array}$} \\
\hline & & 1 & 2 & 3 & 4 & 1 & 2 & 3 & 4 \\
\hline $\begin{array}{l}\text { Everyday use } \\
\text { of media plat- } \\
\text { forms (17) }\end{array}$ & $\begin{array}{l}\text { Use of traditional platforms } \\
\text { (linear and physical) vs digital } \\
\text { platforms }\end{array}$ & 33.1 & 0.4 & 0.1 & 0.0 & 0.85 & -0.08 & -0.03 & 0.01 \\
\hline $\begin{array}{l}\text { (RV total MFA } \\
=.58)\end{array}$ & $\begin{array}{l}\text { Use of TV series, movies, \& } \\
\text { social media vs not. }\end{array}$ & 1.1 & 2.3 & 22.4 & 4.6 & 0.17 & 0.21 & 0.60 & 0.23 \\
\hline
\end{tabular}


Table $2 \boldsymbol{b}$ The pseudoseparate analyses of the overall MFA: Characteristics and selected statistics for specific brand use

\begin{tabular}{|c|c|c|c|c|c|c|c|c|c|}
\hline \multirow[b]{2}{*}{ Variable } & \multirow[b]{2}{*}{ Pseudoseparate axes } & \multicolumn{4}{|c|}{$\begin{array}{l}\text { Absolute contribution to } \\
\text { global axes } \\
\text { (bold = above average) }\end{array}$} & \multicolumn{4}{|c|}{$\begin{array}{l}\text { Correlation with } \\
\text { global axes } \\
\text { (bold }=>.30)\end{array}$} \\
\hline & & 1 & 2 & 3 & 4 & 1 & 2 & 3 & 4 \\
\hline \multirow{3}{*}{$\begin{array}{l}\text { Use of chan- } \\
\text { nels, publica- } \\
\text { tions, and net } \\
\text { sites (56) } \\
\text { (RV total MFA } \\
=.63 \text { ) }\end{array}$} & $\begin{array}{l}\text { Streaming services vs tradi- } \\
\text { tional TV (e.g., cable) }\end{array}$ & 16.1 & 4.2 & 14.1 & 22.3 & -0.59 & -0.25 & 0.43 & 0.46 \\
\hline & Many vs fewer brands & 4.2 & 9.5 & 7.6 & 5.6 & 0.39 & 0.49 & 0.41 & 0.30 \\
\hline & $\begin{array}{l}\text { News and culture in traditio- } \\
\text { nal media vs social media, } \\
\text { streaming, \& cable TV }\end{array}$ & 3.9 & 9.4 & 7.6 & 0.3 & -0.39 & 0.50 & -0.42 & 0.07 \\
\hline
\end{tabular}

Table 2c The pseudoseparate analyses of the overall MFA: Characteristics and selected statistics for interest in news categories in newspapers

\begin{tabular}{|c|c|c|c|c|c|c|c|c|c|}
\hline \multirow[b]{2}{*}{ Variable } & \multirow[b]{2}{*}{ Pseudoseparate axes } & \multicolumn{4}{|c|}{$\begin{array}{l}\text { Absolute contribution to } \\
\text { global axes } \\
\text { (bold = above average) }\end{array}$} & \multicolumn{4}{|c|}{$\begin{array}{l}\text { Correlation with } \\
\text { global axes } \\
\text { (bold }=>.30)\end{array}$} \\
\hline & & 1 & 2 & 3 & 4 & 1 & 2 & 3 & 4 \\
\hline $\begin{array}{l}\text { Interest in } \\
\text { news catego- } \\
\text { ries }(23)\end{array}$ & $\begin{array}{l}\text { Higher vs lower interest for } \\
\text { foreign news, politics, com- } \\
\text { merce, high culture, \& debate }\end{array}$ & 3.2 & 34.1 & 2.1 & 0.6 & -0.26 & 0.72 & 0.17 & -0.08 \\
\hline $\begin{array}{l}(\mathrm{RV} \text { total MFA } \\
=.49)\end{array}$ & $\begin{array}{l}\text { Higher vs lower interest in } \\
\text { lifestyle content and popular } \\
\text { culture }\end{array}$ & 1.1 & 0.5 & 2.2 & 21.8 & 0.21 & -0.12 & 0.23 & -0.63 \\
\hline
\end{tabular}

Table 2d The pseudoseparate analyses of the overall MFA: Characteristics and selected statistics for interest in television programmes

\begin{tabular}{|c|c|c|c|c|c|c|c|c|c|}
\hline \multirow[b]{2}{*}{ Variable } & \multirow[b]{2}{*}{ Pseudoseparate axes } & \multicolumn{4}{|c|}{$\begin{array}{c}\text { Absolute contribution to } \\
\text { global axes } \\
\text { (bold = above average) }\end{array}$} & \multicolumn{4}{|c|}{$\begin{array}{l}\text { Correlation with } \\
\text { global axes } \\
(\text { bold }=>.30)\end{array}$} \\
\hline & & 1 & 2 & 3 & 4 & 1 & 2 & 3 & 4 \\
\hline \multirow{3}{*}{$\begin{array}{l}\text { Interest in TV } \\
\text { programmes } \\
(42) \\
\text { (RV total MFA } \\
=.66)\end{array}$} & $\begin{array}{l}\text { Higher vs lower interest for } \\
\text { Norwegian prime time pro- } \\
\text { gramming }\end{array}$ & 26.1 & 0.0 & 3.4 & 20.2 & 0.75 & 0.02 & -0.21 & 0.44 \\
\hline & $\begin{array}{l}\text { Interest in fewer vs more } \\
\text { programmes from list }\end{array}$ & 5.4 & 7.7 & 23.5 & 8.3 & 0.36 & 0.36 & 0.58 & -0.30 \\
\hline & $\begin{array}{l}\text { Interest in debate/news vs } \\
\text { light entertainment, talk, \& } \\
\text { reality shows }\end{array}$ & 0.8 & 26.5 & 9.1 & 2.6 & 0.15 & -0.72 & 0.39 & -0.18 \\
\hline
\end{tabular}

Comments: Absolute contribution shows the share of the global axis determined by oppositions on the selected pseudoseparate axis. Correlations suggest general alignment between the latter axis and the global axes ( 0 = no correlation, $1=$ perfect correlation). RV is a general measure of the alignment between the axes of the partial analysis and the global analysis ( 1 = perfect). Note that while the top five axes for each group were used to construct the global space (the full MFA), only the significant axes are shown here.

\section{Four subspaces of everyday media use}

There are four variable groups in our analysis with their own internal oppositions. Group A - use of media platforms - concerns uses at least five days a week of 17 forms of basic media types (e.g., television, newspaper, social media, video games) in digital 
and non-digital variants. It mainly discerns ${ }^{3}$ citizens according to 1) more versus less everyday use of traditional and linear media (e.g., print newspapers, direct radio, and television), and 2) more versus less use of television drama, movies, and social media. Group B - regular use of brands - involves selections from lists of 56 newspapers, radio and television channels, news sites, streaming services, and social media. The main differences are between 1) the use of streaming services versus cable television, 2) the use of many versus fewer brands, and 3) use of traditional news and culture newspapers and channels (e.g., Aftenposten, Klassekampen, NRK P1 and P2) versus the use of social media, streaming services, and cable television. Group C - preferred content in newspapers - concerns respondents' answers of whether they were interested in 23 types of news content, separating people along 1) those who mention themselves as interested in foreign news, political genres, high culture, and debate genres versus those who do not, and 2) varying interest in lifestyle content (e.g., fashion, beauty, home improvement) and celebrities. Group D - preferences for television programmes - concerns respondents' answers of whether they are interested in a varied list of 42 television programmes (news, talk shows, reality series, entertainment shows, drama series, and more). Here, people are divided by 1) liking versus not liking the most popular programmes from Norwegian prime time, 2) selecting many versus fewer programmes on the list, and 3) the enjoyment of debate and news programmes versus light entertainment programmes, talk- and reality shows. The mentioned axes explain more than 90 per cent of the substantial differences for each subspace. ${ }^{4}$

\section{The global space of everyday media use}

Combining the four groups of variables in the global MFA suggests four global axes of difference in people's everyday media use. ${ }^{5}$ The first is found between the left and right part of the map in Figure 2a. At the right, we find people who daily use social media and streaming services, and at the left we find people whose media use is centred around direct-TV and radio (mostly for news), reading of print newspapers, and with a greater interest in local news. This axis distinguishes mainly between traditional and newer forms of media use and younger and older generations.

The second difference is found between the upper and lower side in the same map and mainly concerns media content. Those on the top are more often interested in the news (in particular national and international news), in documentaries, political content and debate (also cultural discussion), and brands associated with such content. They also appear as more avid users of streaming services and with a higher interest in "complex TV" (Mittell, 2015) dramas - often engaging with contested issues in society - with complex characters and narrative forms (e.g., The Wire, Skam, House of Cards, and Narcos). Rather than just interest in news, the difference thus appears to concern a more general different engagement and interest in the world of politics and public debate on a national and international level. This difference is linked to the educational level, and, as we shall see later, capital volume.

The third axis (not shown in the map), like the first, separates people by their daily use versus non-use of digital media (social media, net newspapers, computer games, and television streaming in particular), but also by higher versus lower interest and use of commercial television entertainment and news. A closer inspection suggests that this 
axis primarily separates the very oldest group from the rest and can be considered a variation of the first axis. ${ }^{6}$ For this reason, we ignore this axis in the rest of the discussion.

The fourth axis (shown in figure $2 b$, together with the second axis) emphasises gender differences and varying interest in culture and entertainment. At the right side of the model, the axis separates the most-male oriented sports- and documentary-oriented cable channels (e.g., Discovery, Max, Viasat) and content (sport, motor, tech) from types of popular cultural entertainment - typically more popular with female audiences - including chat programmes (Senkveld, Lindmo, Skavlan), programmes about home improvement (Tid for hjem), celebrity news (God morgen Norge), and series like Paradise Hotel and Grey's Anatomy. The axis also separates those interested and not interested in reading cultural reviews in the newspapers, of both popular and more highbrow forms, making it reasonable to interpret this as a general axis for interest in culture, and linked to cultural capital, while at the same time also being clearly gendered.

Figure 2a The space of media practices and preferences in Norway (MFA, axis 1-2)

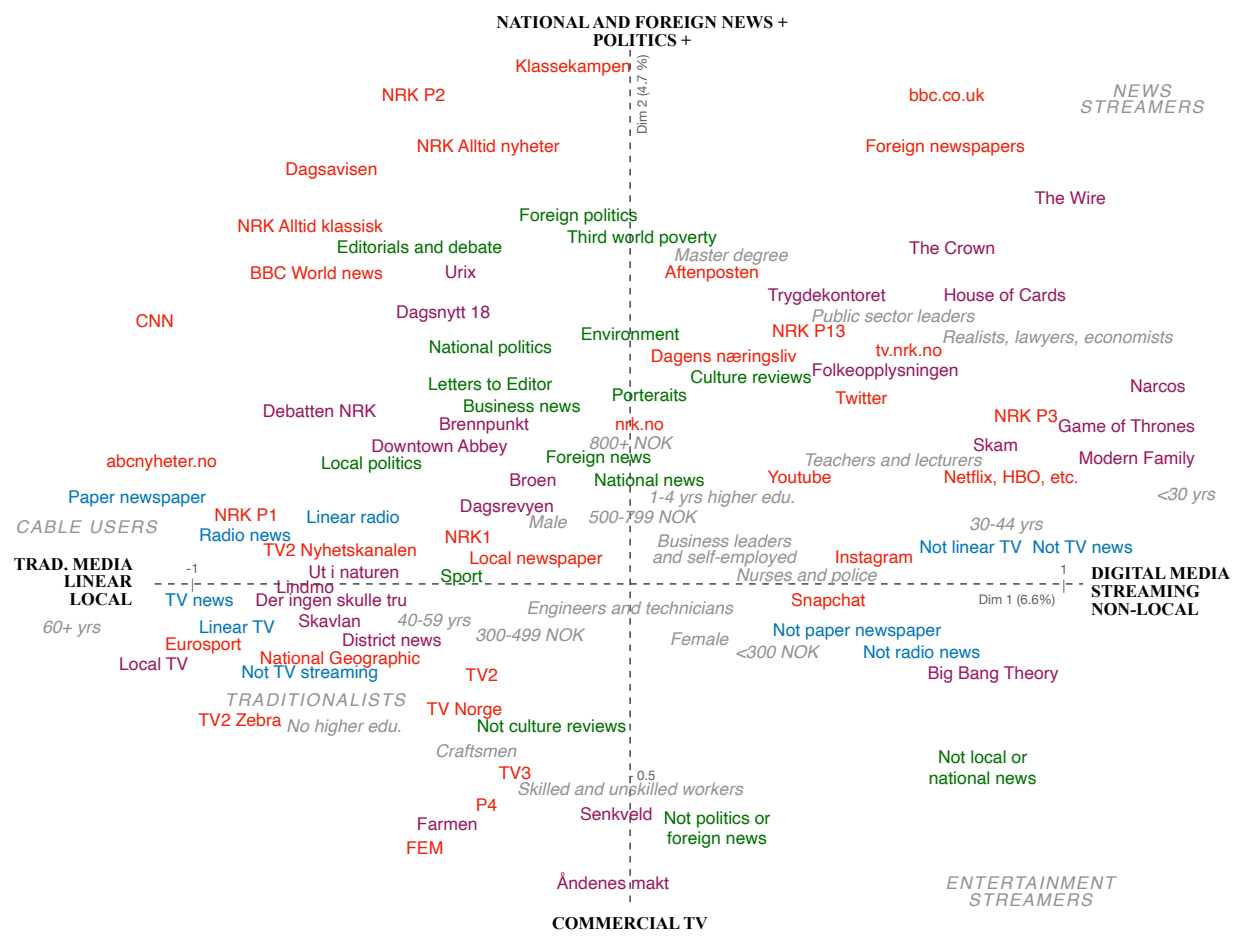

Comments: Best represented categories in axis plane $\left(\cos ^{2}>0.2\right)$ and selected social categories.

Source: Created by the authors 
Figure $\mathbf{2 b}$ The space of media practices and preferences in Norway (MFA, axis 2-4)

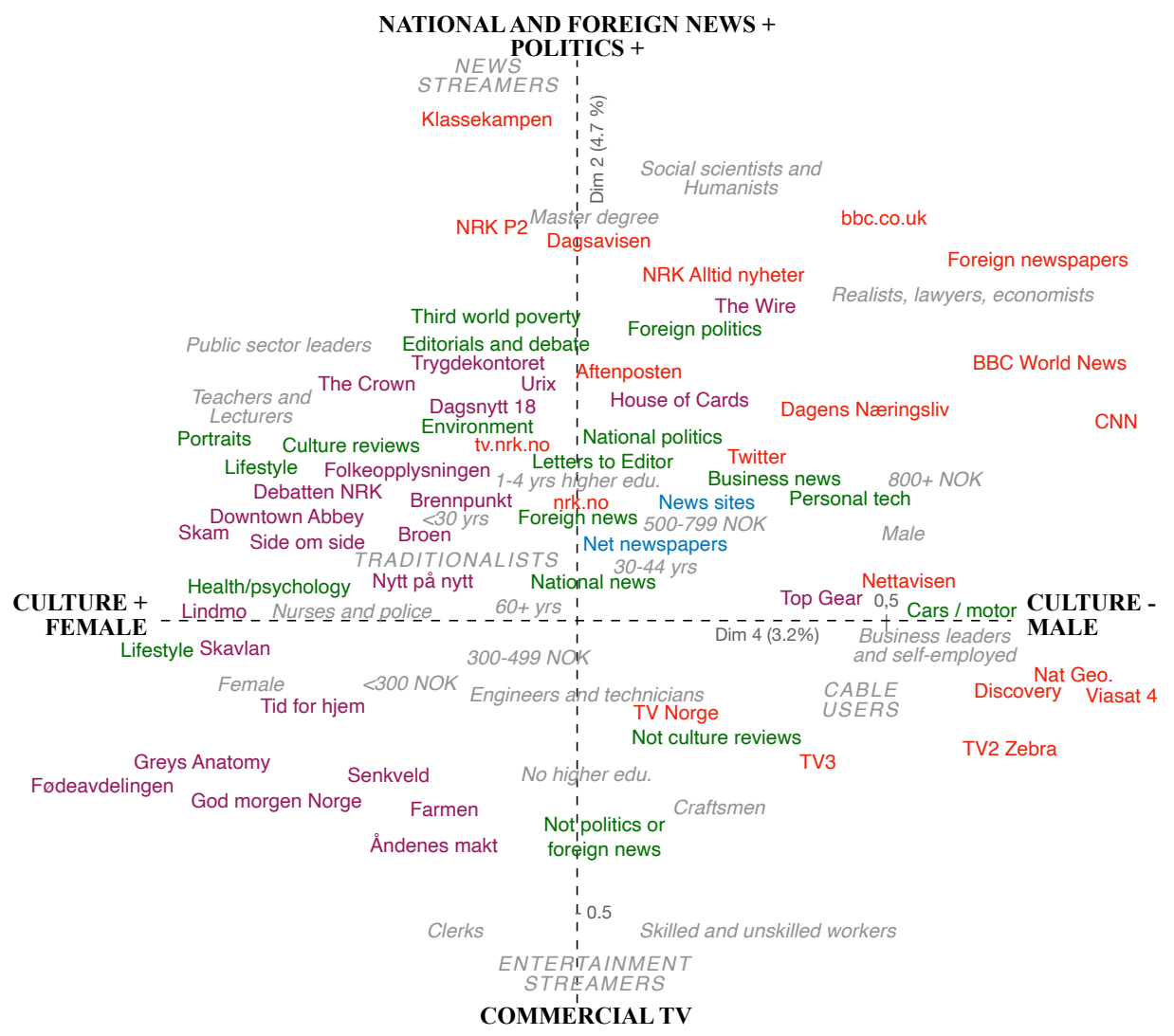

Comments: Best represented categories in axis plane $\left(\cos ^{2}>0.2\right)$ and selected social categories.

Source: Created by the authors

The salience of the four dimensions we have found - linked to generations' different use of media services (often related to digital technology), and varying interest in news and culture - can be further illustrated by the major groupings in this space. Using cluster analysis (HCPC) on individuals' positions (including ten axes, not only the first two), we identify four groups roughly divided along the two first axes in Figure 2a. To the right, we find the two oldest groups. "Traditionalists" are characterised by the centrality of paper newspapers and linear public broadcasting (NRK, to a lesser degree TV2). Only half of them use social media daily (which is much less than the other groups). Linear television is also central to "cable users", but for the latter, commercial television has a more significant role, and they less often read print newspapers. They are also more likely than the former to use digital platforms, net newspapers, and social media. They are more often male and somewhat younger and more educated than the traditionalists. In the left part of the same map, we find two younger groups. "Entertainment streamers" are more often female and include both more youthful and middle-aged people. Their media repertoires are characterised by entertainment and streaming services, with television series, reality- and talk-shows, lifestyle content, celebrities, and social media use. They are less likely to read newspapers and watch regular television channels and appear interested in fewer news categories. They are contrasted by "news-oriented streamers", 
active users of streaming services and digital content, with a particular interest in the types of complex television we talked about earlier, and in debates, politics, and international news. These are often young, with higher education. The traditionalists and entertainment streamers are opposed to the cable users and news-oriented streamers via the second axis, due partly to lower interest and use of news - and particularly, political content (four clusters is the optimal solution following the criteria of the lowest ratio between two succeeding intra-group intertias).

\section{Media use, generations, and class}

The finding of age as the significant variable for explaining differences between media users in our analysis is in line with arguments that the shift from analogue to digital media has increased generational differences in media use (see, e.g., Buckingham, 2006). It also connects with arguments that age differences are somewhat of an omitted variable in class studies of culture (Edmunds \& Turner, 2002; Glevarec \& Cibois, 2020). And this part of our findings can comfortably be interpreted as one of different media "generations" in a Bourdieuan reading of Mannheim (2005), as "a cohort of persons passing through time who come to share a common habitus, hexis and culture, a function of which is to provide them with a collective memory that serves to integrate the cohort over a finite period of time" (Eyerman \& Turner, 1998: 93). Such a "generation effect" is most clearly found in regard to the adoption of services and platforms which were available at formative times in their lives, which can be illustrated with the older generations lower use of digital service and higher preference for public broadcasting (the first commercial television station was not established in Norway until 1991).

When we look at how the different generations are internally divided in their media use - which is mostly about what kinds of content they use - we would expect them to be quite different. But on the contrary, they are homological - divided along similar lines. This is clearly suggested by how the second axis in Figure 2a, for both older and younger generations, separates people by their varying orientation towards national and international news and politics. To investigate this further, we re-ran the former MFA analysis separately for the youngest $(<35, N=457)$, and oldest $(60+, N=754)$ groups. The first axis was, for both groups, linked to similar traits in their daily media use: a generally higher versus lower interest and use of news; being interested in politics (in particular national and foreign), debate, and foreign news either in newspaper or television form or not; and varying preference for the public broadcaster NRK versus commercial broadcasting. For both age groups, these differences in media use were, furthermore, linked to comparable indicators of higher versus lower capital volume (primarily cultural capital), both accumulated (e.g., via own education) or inherited (e.g., via parents' education), which suggests their persistent potential to function as valuable marks of cultural distinction.

There are also some interesting variations. For the oldest group, platforms matter, as non-use of radio and net newspapers are linked to lower-class backgrounds, and higherclass backgrounds are more likely to read national newspapers and listen to radio news and culture (NRK channel P2). For the youngest, in contrast, there are no striking differences in the use of platforms or specific newspapers, but the use of complex television drama (e.g., The Wire) are opposed to popular television entertainment (e.g., Grey's 
Anatomy or reality and chat shows). While these results no doubt reflect that television entertainment is more oriented towards the young than the old, this might also suggest the appreciation of complex television drama as an emerging form of cultural capital (Prieur \& Savage, 2013).

This relevance of the class dimension can be easily demonstrated by the distribution of class fractions for different age groups (see Figure 3) in the space of media use (as shown in the earlier Figures $2 a-b$ ). In the left side of Figure 3 (showing axis 2-1), we see that whereas the first (horizontal) axis separates generations, it appears to have no relation to class. In contrast, the placement of class fractions in the right side of Figure 3 (axis 2-4) reproduces the overall structure of the social space as sketched in Figure 1. Stronger versus lesser orientation to national and international news and politics aligns with the axis of capital volume, and a stronger versus lesser orientation towards the world of mediated culture aligns with the axis of capital composition. We are left with the conclusion that the dominant patterns of everyday media use, when we look beyond the generational differences, basically reflects the underlying (gendered) social space. It is a three-dimensional model, a succession of overlapping social spaces distributed along the time dimension. This suggests remarkable underlying stability in how class differences structure differences in people's everyday media use, and the continuing relevance of classes for understanding such variations.

Figure 3 Class fractions in the space of everyday media use (dimensions 2-1 \& 2-4)
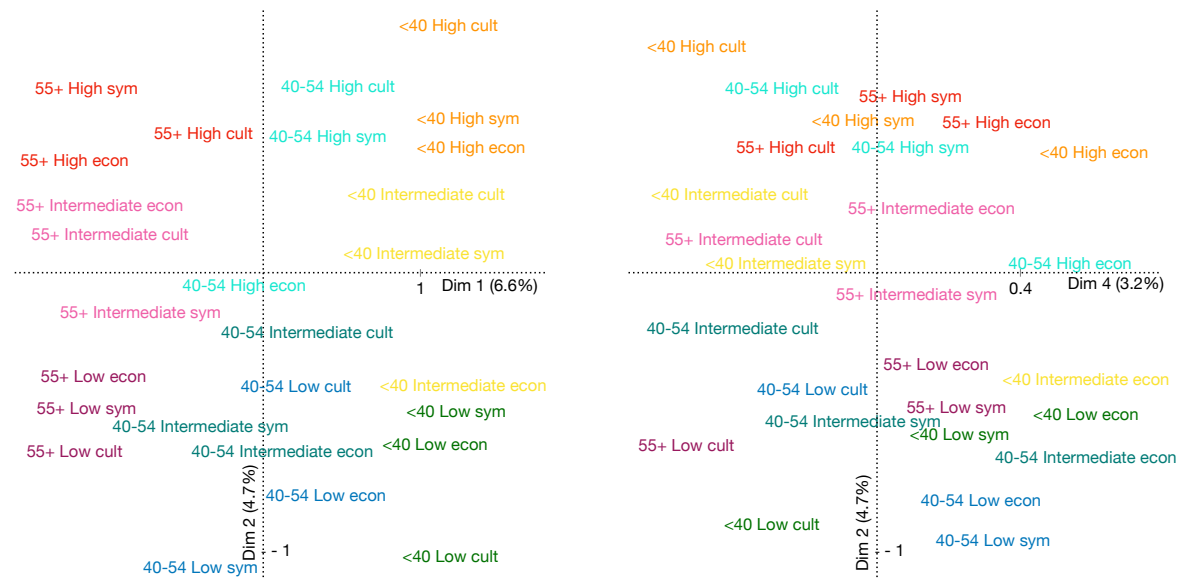

Comments: "Low", "Intermed", and "High" refer to the vertical dimension of the social space in Figure 1, "cult" and "econ" refer to cultural and economic fractions, and "sym" to a balanced (symmetric) capital composition.

Source: Created by the authors

\section{Conclusions}

Regardless of claims of the death (or at least, increasing irrelevance) of class as an explanatory variable in the sociology of culture, our investigations into the everyday media use of Norwegians demonstrate the central and continuing relevance of social class for structuring people's everyday media practices in late-modern - and in the Nordic case, relatively egalitarian - digitally advanced societies. Other variables are, of course, also 
clearly important. Gender differences, for example, are strongly linked to varying interest in different forms of lifestyle and culture and the use of different media brands (e.g., television channels). In our material, generational differences are also very distinctive, and like gender, are no doubt linked to other, important differences in people's dispositions and modes of consumption (Bourdieu, 1984) of media content than those we have been able to show by our data and methods. At the same time, the generational differences also appear somewhat superficial. They concern mainly different adaption and use of "legacy" versus "modern" media and services, and to lesser degree the substance of these services - that is, what kind of general content people regularly use and are interested in, and via that, what types of symbolic and social worlds they connect with.

What divides people in this latter, and more important, aspect appears, in contrast, fundamentally similar in all age groups. It concerns, first, a varying orientation towards the world of national and international mainstream news, especially concerning politics, and second, towards the world of culture. This orientation is significantly related to class position. The higher position in the social space, the more often people say of themselves that they are interested in the first (e.g., politics), and the more their resources are dominated by cultural capital rather than economic capital, their interest is directed towards the latter (culture). Our findings in this way also suggest the continuing relevance of Bourdieu's (1984) original analysis, including the thesis of a homology between social classes and lifestyles.

In regard to the link between interest in culture and class, as demonstrated in some people's stronger relation to both mediated (e.g., television dramas) and unmediated culture (e.g., literature discussed in newspaper reviews), in particular by those fractions associated with cultural capital, this is well-documented in class literature (e.g., Bennett et al., 2009; Rosenlund, 2015). The dispositions for culture are formed in the habitus first via social inheritance (often via culturally interested and active parents) and are typically strengthened by life choices (e.g., educational field) and lifestyles which are more probable (if not determined) because of this (Bourdieu, 1984). It thus seems not so surprising that different tastes for culture should play a significant part in structuring people's everyday media use, not least given that a majority of such use is for entertainment rather than news and debate formats (Schiro, 2018). Brands and publications are also often actively geared towards specific cultural tastes and social segments for advertisement considerations (e.g., television channels trying to reach primarily male or female audiences), sometimes achieved, somewhat ironically, using the same theories class sociologists use to investigate the differences the former actively try to produce.

What, then, about people's different interest in news in general and politics? A key point for Bourdieu was that when we talk about people's "interest" in something, like "political news", we often focus on the first meaning of the word, as something that holds our interest, and forget the second meaning - that is, as something we have an investment in (as in a house or a company) and our position is bound to. As suggested in Bourdieu's Distinction (1984), the fundamental explanation for some people's stronger orientation towards the worlds of politics and other social elites (which is what is implied with monikers like "serious" news - a word whose etymology means being both important and honoured) is that they are to a greater degree connected to these worlds, in manifold ways, via investments and belongings which make a sum greater than its parts: education, friends, place of work, areas of expertise, and so on. Viewed in this way, 
the persistent correlation between reading about what elites do and say and closeness to the same elites (in terms of social position, which is not just a question of vertical distance - that is, capital volume, but also of the societal sector, related to capital composition) is entirely to be expected. It also makes it absurd to expect that this fact can be changed, quasi-magically, simply by educational or motivational efforts, by changes in news formats and presentation, and so on. We would not expect people in Amsterdam to be more interested in the news from Berlin than from their hometown - why should social (that is, class) distances matter less than geographical distances from the events and milieus described? Everyone loves local news, but what counts as local news for someone is just as much a matter of social class as of geography (Hovden, 2021).

Because of the fundamental link between our position in the social space and the social and symbolic worlds media connect us with, it should not be surprising that class position should appear as a fundamental explanatory principle for people's everyday media use, which, reversely, offers a rich source of cultural distinction in modern societies. The combination of a more diverse and readily available landscape of mediated cultural goods and increasing social inequality - also in the Scandinavian societies (Aaberge \& Atkinson, 2010; Piketty, 2020) - indicates, if anything, that class will become more, not less, important for understanding patterns of everyday media use in the foreseeable future.

\section{Funding}

The authors received financial support for the data collection from the Research Council of Norway (grant no. 247617).

\section{Notes}

1 For such reasons, class analyses of cultural use have traditionally concerned themselves with very small selections of homogenous practices. See, for example, Bennet and colleagues (2009), and also their critique of this as a major shortcoming of important earlier studies (Chan \& Goldthorpe, 2004; Peterson, 1992).

2 Eigenvalues and explained variance (Benzécri) for the first five axes: $0.23(40 \%), 0.19(18 \%), 0.17$ $(10 \%), 0.15(6 \%)$, and $0.14(4 \%)$. The third and fourth axes appear as variations of the two first and will be ignored in the following analysis.

3 Principal axes following weighted correspondence analysis. Only significant axes are discussed.

4 Explained inertia (Benzécris modified values) for the axes (by number) in the respective subspaces (platforms: $65 \%$ and $31 \%$; news categories: $85 \%$ and $10 \%$; brands: $62 \%, 17 \%$, and $12 \%$; TV programmes: $42 \%, 33 \%$, and $19 \%$ ).

5 Eigenvalues and percent explained inertia for the five first axes: $2.21(6.6 \%), 1.58(4.7 \%), 1.37$ (4.1 $\%), 1.10(3.2 \%)$, and $0.81(2.4 \%)$.

6 The reason for this is probably a mix of substantial and methodological issues - linked to both a very real gap between the oldest and the later generations in their everyday media use but also probably some age bias in the questionnaire, being geared more towards the media practices of younger generations.

\section{References}

Aaberge, R., \& Atkinson, A. B. (2010). Top incomes in Norway. In A. B. Atkinson, \& T. Piketty (Eds.), Top incomes: A global perspective (pp. 448-480). Oxford: Oxford University Press.

Adkins, L., \& Skeggs, B. (Eds.). (2005). Feminism after Bourdieu. Oxford: Blackwell.

Atkinson, W. (2015). Class. Oxford: Polity Press.

Baym, N. K. (2015). Personal connections in the digital age. Hoboken, New Jersey: John Wiley \& Sons. Beck, U. (1992). Risk society. London: Sage.

Bennett, T., Savage, M., Silva, E. B., Warde, A., Gayo-Cal, M., \& Wright, D. (2009). Culture, class, distinction. London: Routledge. https://doi.org/10.4324/9780203930571 
Blekesaune, A., Elvestad, E., \& Aalberg, T. (2010). Tuning out the world of news and current affairs - An empirical study of Europe's disconnected citizens. European Sociological Review, 28(1), 110-126. https://doi.org/10.1093/esr/jcq051

Blumer, H. (1956). Sociological analysis and the variable. American Sociological Review, 21(6), 683-690. https://doi.org/10.2307/2088418

Bourdieu, P. (1984). Distinction: A social critique of the judgement of taste. London: Routledge/Kegan Paul.

Bourdieu, P., \& Passeron, J.-C. (1979). The inheritors: French students and their relation to culture. Chicago: University of Chicago Press.

Bourdieu, P., \& Passeron, J.-C. (1990). Reproduction in education, society and culture. London: Sage.

Bourdieu, P., \& Wacquant, L. J. (1992). An invitation to reflexive sociology. Chicago: University of Chicago Press.

Buckingham, D. (2006). Is there a digital generation? In D. Buckingham, \& R. Willet (Eds.), Digital generations: Children, young people, and new media (pp. 1-18). New York: Lawrence Erlbaum Associates.

Chan, T. W., \& Goldthorpe, J. H. (2004). Social stratification and musical consumption: Music in England. Oxford: University of Oxford Press.

Coulangeon, P., \& Duval, J. (Eds.). (2014). The Routledge companion to Bourdieu's 'Distinction'. London: Routledge. https://doi.org/10.4324/9781315852539

Danielsen, A. (2006). Behaget i kulturen [The pleasure in culture and the arts]. Oslo: Norsk Kulturråd.

Edmunds, J., \& Turner, B. S. (2002). Generations, culture and society. Buckingham, UK: Open University Press.

Eyerman, R., \& Turner, B. S. (1998). Outline of a theory of generations. European Journal of Social Theory, 1(1), 91-106. https://doi.org/10.1177/136843198001001007.

Flemmen, M., Jarness, V., \& Rosenlund, L. (2018). Social space and cultural class divisions: The forms of capital and contemporary lifestyle differentiation. Br J Sociol, 69(1), 124-153. https://doi.org/10.1111/14684446.12295

Gallup. (2017). Media use, culture \& public connection. Oslo: Gallup.

Giddens, A. (1991). Modernity and self-identity: Self and society in the late modern age. Stanford: Stanford University Press.

Glevarec, H., \& Cibois, P. (2020). Structure and historicity of cultural tastes. Cultural Sociology, 21(1). https:// doi.org/10.1177/1749975520947590

Goldthorpe, J. H. (1980). Social mobility and class structure in modern Britain. Oxford: Clarendon Press.

Grignon, C., \& Passeron, J.-C. (2019). Le savant et le populaire: Misérabilisme et populisme en sociologie et en littérature [The scholar and the popular: Miserabilism and populism in sociology and literature]. Paris: Le Seuil.

Gripsrud, J., \& Hovden, J. F. (2000). (Re)producing a cultural elite? In J. Gripsrud (Ed.), Sociology, culture \& aestethics (pp. 55-90). Oslo: Høyskoleforlaget/NFR.

Gripsrud, J., Hovden, J. F., \& Moe, H. (2011). Changing relations: Class, education and cultural capital. Poetics, 39(6), 507-529. https://doi.org/doi.org/10.1016/j.poetic.2011.09.007

Hasebrink, U., \& Domeyer, H. (2012). Media repertoires as patterns of behaviour and as meaningful practices: A multimethod approach to media use in converging media environments. Participations, 9(2), 757-779.

Hasebrink, U., \& Popp, J. (2006). Media repertoires as a result of selective media use: A conceptual approach to the analysis of patterns of exposure. Communications, 31(3), 369-387. https://doi.org/10.1515/COMMUN.2006.023

Hjellbrekke, J., Jarness, V., \& Korsnes, O. (2015). Cultural distinctions in an 'egalitarian' society. In P. Coulangeon, \& J. Duval (Eds.), The Routledge companion to Bourdieu's distinction (pp. 187-206). London: Routledge. https://doi.org/10.4324/9781315852539

Hovden, J. F. (2021). Dårlige borgere? Arbeiderklassene i den moderne offentligheten [Bad citizens? The working class in the modern public sphere]. In M. N. Hansen, \& J. Ljunggren (Eds.), Arbeiderklassen [Working classes] (pp. 353-369). Oslo: Cappelen Damm.

Inglehart, R. (1990). Culture shift in advanced industrial society. Princeton, New Jersey: Princeton University Press.

Lahire, B. (2004). La Culture des individus [The culture of individuals]. Paris: La Découverte.

Lamont, M., \& Lareau, A. (1988). Cultural capital: Allusions, gaps and glissandos in recent theoretical developments. Sociological Theory, 6(2), 153-168. https://doi.org/10.2307/202113

Le Roux, B., \& Rouanet, H. (2010). Multiple correspondence analysis. London: Sage.

Le Roux, B., Rouanet, H., \& Ackermann, W. (2000). The geometric analysis of questionnaires: The lesson of Bourdieu's La Distinction. Bulletin de Méthodologie Sociologique, (65), 5-18. https://www.jstor. org/stable/23894151

Lebart, L., Morineau, A., \& Warwick, K. M. (1984). Multivariate descriptive statistical analysis correspondence analysis and related techniques for large matrices. New York: Wiley. 
Lindell, J., \& Hovden, J. F. (2018). Distinctions in the media welfare state: Audience fragmentation in post-egalitarian Sweden. Media, Culture \& Society, 40(5), 639-655. https://doi.org/10.1177/0163443717746230

Livingstone, S. (1999). New media, new audiences? New media \& society, 1(1), 59-66.

Mangset, P. (2012). Er demokratisering av kulturen mulig? [Is democratization of culture possible?]. In J. F. Hovden, \& K. Knapskog (Eds.), Hunting high and low (pp. 588-613). Oslo: Scandinavian Academic Press.

Mannheim, K. (2005). The problems of generations. In C. Jenks (Ed.), Childhood: Critical concepts in sociology (pp. 273-285). London: Routledge.

Mittell, J. (2015). Complex TV: The poetics of contemporary television storytelling. New York: New York University Press.

Moe, H., Hovden, J. F., Ytre-Arne, B., Figenschou, T., Nærland, T. U., Sakarissaen, H., \& Thorbjørnsrud, K. (2019). Informerte borgere? [Informed citizens?]. Oslo: Scandinavian University Press.

Morley, D. G. (1980). The nationwide audience. London: British Film Institute.

Pagès, J., \& Bécue-Bertaut, M. (2006). Multiple factor analysis for contingency tables. In M. Greenacre, \& J. Blasius (Eds.), Multiple correspondence analysis and related methods (pp. 299-326). London: Chapman \& Hall.

Pagès, J. (2014). Multiple factor analysis by example using R. London: Routledge. https://doi.org/10.1201/ b17700

Peterson, R. A. (1992). Understanding audience segmentation: From elite and mass to omnivore and univore. Poetics, 21(4), 243-258. https://doi.org/10.1016/0304-422X(92)90008-Q

Piketty, T. (2020). Capital and ideology. Cambridge, Massachusetts: Harvard University Press.

Prieur, A., Rosenlund, L., \& Skjott-Larsen, J. (2008). Cultural capital today: A case study from Denmark. Poetics, 36(1), 45-71. https://doi.org/10.1016/j.poetic.2008.02.008

Prieur, A., \& Savage, M. (2013). Emerging forms of cultural capital. European Societies, 15(2), 246-267. https://doi.org/10.1080/14616696.2012.748930

Rosenlund, L. (2000). Social structures and change. Stavanger, Norway: Høgskulen i Stavanger.

Rosenlund, L. (2009). Exploring the city with Bourdieu: Applying Pierre Bourdieu's theories and methods to study the community. Riga: VDM Publishing.

Rosenlund, L. (2015). Working with distinction: Scandinavian experiences. In P. Coulangeon, \& J. Duval (Eds.), The Routledge companion to Bourdieu's Distinction (pp. 157-186). London: Routledge. https:// doi.org/10.4324/9781315852539

Rosenlund, L. (2019). The persistence of inequalities in an era of rapid social change: Comparisons in time of social spaces in Norway. Poetics, 74, 101323. https://doi.org/10.1016/j.poetic.2018.09.004

Schiro, E. C. (2018). Norsk mediebarometer 2019 [Norwegian media trends 2019]. Oslo: SSB.

Tsatsou, P. (2011). Digital divides revisited: What is new about divides and their research? Media, Culture \& Society, 33(2), 317-331. https://doi.org/10.1177/0163443710393865

Wright, E. O. (1985). Classes. New York: Verso. 


\section{Appendix 1}

Table A1 Differences by class fraction for everyday use of television programmes (odds ratios)

\begin{tabular}{lcc}
\hline & $\begin{array}{c}\text { Higher classes } \\
\text { (vs lower) }\end{array}$ & $\begin{array}{c}\text { Cultural fractions } \\
\text { (vs economic) }\end{array}$ \\
\hline Dagsnytt 18 & 2.4 & 1.3 \\
House of Cards & 2.1 & 0.9 \\
Skam & 1.9 & 1.2 \\
Dagsrevyen & 1.4 & 1.2 \\
Nytt på Nytt & 1.3 & 1.3 \\
Skavlan & 0.9 & 1.2 \\
Top Gear & 0.9 & 0.4 \\
Stjernekamp & 0.8 & 1.1 \\
TV2 News & 0.7 & 0.8 \\
Tid for hjem & 0.7 & 0.8 \\
Der ingen skulle tru & 0.7 & 1.0 \\
District news & 0.6 & 1.0 \\
Paradise Hotel & 0.4 & 1.3 \\
Farmen & 0.4 & 0.9 \\
\hline
\end{tabular}

Comments: Odds ratios (OR) following logistic regression with control for age. OR is the probability that an event for one group is true versus being true for another group, where $1=$ no difference, 2 = double, 0.5 = half, etc.

Table A2 Differences by class fraction for everyday use of newspaper brands (odds ratios)

\begin{tabular}{lcc}
\hline & $\begin{array}{c}\text { Higher classes } \\
\text { (vs lower) }\end{array}$ & $\begin{array}{c}\text { Cultural fractions } \\
\text { (vs economic) }\end{array}$ \\
\hline The Guardian & 7.5 & 2.1 \\
Aftenposten & 5.1 & 1.2 \\
Morgenbladet & 4.8 & 3.5 \\
Dagens næringsliv & 3.7 & 0.4 \\
bbc.co.uk & 3.5 & 1.4 \\
cnn.com & 3.3 & 0.9 \\
Klassekampen & 3.4 & 3.6 \\
Foreign newspapers & 3.3 & 1.1 \\
nrk.no & 1.8 & 1.2 \\
Dagbladet & 1.3 & 1.1 \\
Nettavisen & 0.9 & 0.6 \\
VG & 0.9 & 0.8 \\
Local newspapers & 0.8 & 0.9 \\
ABCnyheter & 0.8 & 1.1 \\
Buzzfeed & 0.8 & 2.8 \\
Sol.no & 0.5 & 0.7 \\
\hline
\end{tabular}

Comments: Odds ratios (OR) following logistic regression with control for age. OR is the probability that an event for one group is true versus being true for another group, where 1 = no difference, 2 = double, 0.5 = half, etc. 
Jan Fredrik Hovden \& Lennart Rosenlund

Table A3 Differences by class fraction for everyday use of newspaper categories (odds ratios)

\begin{tabular}{lcc}
\hline & $\begin{array}{c}\text { Higher classes } \\
\text { (vs lower) }\end{array}$ & $\begin{array}{c}\text { Cultural fractions } \\
\text { (vs economic) }\end{array}$ \\
\hline Foreign news & 2.8 & 1.1 \\
Culture reviews & 2.8 & 2.0 \\
Commerce & 2.6 & 0.3 \\
Debate columns & 2.5 & 1.2 \\
National politics & 2.4 & 0.9 \\
National news & 2.0 & 0.8 \\
Local politics & 1.4 & 0.8 \\
Lifestyle & 1.4 & 1.6 \\
Sport & 1.1 & 0.5 \\
Local news & 0.8 & 0.7 \\
Celebrities & 0.7 & 1.7 \\
\hline
\end{tabular}

Comments: Odds ratios (OR) following logistic regression with control for age. OR is the probability that an event for one group is true versus being true for another group, where 1 = no difference, 2 = double, 0.5 = half, etc.

Table A4 Differences by class fraction for everyday use of television brands (odds ratios)

\begin{tabular}{lcc}
\hline CNN & $\begin{array}{c}\text { Higher classes } \\
\text { (vs lower) }\end{array}$ & $\begin{array}{c}\text { Cultural fractions } \\
\text { (vs economic) }\end{array}$ \\
\hline Netflix & 1.9 & 0.7 \\
tv.nrk.no & 1.7 & 0.8 \\
NRK1 & 1.6 & 1.2 \\
Youtube & 1.4 & 0.8 \\
Travel Channel & 1.0 & 0.9 \\
TV2 Livsstil & 1.0 & 0.5 \\
TV2 & 0.8 & 1.6 \\
Discovery & 0.7 & 0.5 \\
TV Norge & 0.7 & 0.5 \\
TV 3 & 0.6 & 0.7 \\
TV2 Zebra & 0.6 & 0.6 \\
\hline
\end{tabular}

Comments: Odds ratios (OR) following logistic regression with control for age. OR is the probability that an event for one group is true versus being true for another group, where 1 = no difference, 2 = double, 0.5 = half, etc. 
Table A5 Differences by class fraction for everyday use of radio brands (odds ratios)

\begin{tabular}{lcc}
\hline & $\begin{array}{c}\text { Higher classes } \\
\text { (vs lower) }\end{array}$ & $\begin{array}{c}\text { Cultural fractions } \\
\text { (vs economic) }\end{array}$ \\
\hline NRK Alltid nyheter & 3.8 & 0.9 \\
NRK P2 & 2.7 & 1.2 \\
NRK P13 & 2.1 & 0.6 \\
Foreign radio & 1.7 & 0.9 \\
NRK P3 & 1.6 & 0.7 \\
NRK P1 & 1.4 & 0.8 \\
Local radio & 0.8 & 0.8 \\
P4 & 0.7 & 0.6 \\
Radio Norge & 0.6 & 0.6 \\
\hline
\end{tabular}

Comments: Odds ratios (OR) following logistic regression with control for age. OR is the probability that an event for one group is true versus being true for another group, where $1=$ no difference, 2 = double, $0.5=$ half, etc.

Table A6 Differences by class fraction for everyday use of media and technology (odds ratios)

\begin{tabular}{lcc}
\hline & $\begin{array}{c}\text { Higher classes } \\
\text { (vs lower) }\end{array}$ & $\begin{array}{c}\text { Cultural fractions } \\
\text { (vs economic) }\end{array}$ \\
\hline Newspaper (net) & 2.1 & 0.7 \\
Newspaper (paper) & 1.8 & 0.9 \\
Radio (stream/podc.) & 1.7 & 0.7 \\
Literature & 1.7 & 2.2 \\
TV (streamed) & 1.4 & 0.9 \\
Radio (direct) & 1.4 & 0.7 \\
Social media & 1.1 & 1.2 \\
TV (direct) & 0.9 & 0.8 \\
Computer games & 0.8 & 0.8 \\
TV series & 0.6 & 1.5 \\
Movies & 0.5 & 0.8 \\
\hline
\end{tabular}

Comments: Odds ratios (OR) following logistic regression with control for age. OR is the probability that an event for one group is true versus being true for another group, where 1 = no difference, 2 = double, $0.5=$ half, etc.

(C) 2021 Nordicom and respective authors. This is an Open Access work licensed under the terms of the Creative Commons Attribution-NonCommercial-NoDerivatives 4.0 International Public licence (CC BY-NC-ND 4.0). To view a copy of the licence, visit https://creativecommons.org/ licenses/by-nc-nd/4.0/ 